\title{
The Effect of Participation in Budgeting on Managerial Performance with Locus of Control and Job Relevant Information as Moderating Variables in PT. PLN (PERSERO) UP3 Palu
}

\author{
Saskia Islamay Faizal ${ }^{1}$, Muhammad Din ${ }^{2 *}$, Mustamin ${ }^{2}$, Abdul Kahar ${ }^{2}$, Rahma \\ Masdar $^{2}$, Masruddin $^{2}$ \\ ${ }^{1}$ Student of Accounting Department, Faculty of Economics and Business, Tadulako University, Palu, Indonesia \\ ${ }^{2}$ Lecturer in Accounting Department, Faculty of Economics and Business, Tadulako University, Palu, Indonesia \\ *Corresponding author. Email: muhammaddin@untad.ac.id
}

\begin{abstract}
This study aims to examine the effect of budgetary participation on managerial performance at PT. PLN (Persero) UP3 Palu, the influence of participation in budgeting on managerial performance with Locus of Control as a moderating variable and the influence of participation in budgeting on managerial performance with job relevant information as a moderating variable. This research was conducted using a survey method with a questionnaire as a tool to obtain data. Samples were taken by saturated sampling method. The analytical tool used in processing the data is PLS with the help of WarpPLS software. The results show that budgetary participation has an effect on managerial performance at PT. PLN (Persero) UP3 Palu. Moreover, Locus of Control can moderate or strengthen the relationship between budgetary participation and managerial performance at PT. PLN (Persero) UP3 Palu. Meanwhile, job relevant information can moderate or strengthen the relationship between budgetary participation and managerial performance at PT. PLN (Persero) UP3 Palu.
\end{abstract}

Keywords: Budgetary Participation, Managerial Performance, Locus of Control, Job Relevant Information.

\section{INTRODUCTION}

As State-Owned Enterprises, PT. PLN (Persero) is implementing unit for customer service in Palu. It is required to improve the effectiveness of the company in carrying out its operations through accuracy in budgeting. PT PLN's budget is described in the form of a Corporate Budget Work Plan (RKAP). The budget planning of a program or activity must be thoroughly reviewed with the best possible calculation, with reference to the applicable provisions. Each plan must be adjusted to priorities based on proposals from the lowest work unit or bottom up. In preparing the budget, as far as possible, it is possible to bring together the priority needs with the availability of the budget, so that it can be implemented properly.

Previous research on the relationship between budgetary participation and managerial performance showed inconsistent results. The studies conducted by [1], [2], [3], [4], [5] found that budgeting participation had a positive and significant effect on managerial performance. However, the research of [6] showed that budgetary participation has a negative effect on managerial performance.

The inconsistency of the research results raises gaps so that there is an opportunity for researchers to do further research. Follow-up research serves to provide answers to the inconsistency of the results of previous studies. In the research the effect of budgetary participation on managerial performance can be related to the considered moderating variables. Moderating variables can strengthen or weaken the relationship between budgetary participation and managerial performance. Therefore, this study tries to conduct further research with locus of control and job relevant information as moderating variables with the 
aim of supporting the success factors of a company and achieving the company's vision and mission.

\section{LITERATURE REVIEW}

\subsection{Budgeting Participation}

Participation in budgeting is a managerial approach which is generally considered to have a positive influence on managerial behavior and performance. According to [7], budgetary participation is the participation of operating managers in deciding together with the budget committee regarding the series of activities that will be taken by the operating managers in achieving budget targets. So, it is possible that participation in budget preparation will affect the managerial performance of the government. With the participation of budget preparation, government officials who feel involved will be responsible for budget implementation. Budget participation is a process in which budget makers are involved and have influence in determining the size of the budget. To measure this variable, the research used an instrument according to [8] using 6 indicators, namely involvement in budgeting, the reason for the superior in revising the budget that was prepared or proposed, frequency of giving proposed opinions to superiors, the influence of employees in determining the final budget amount that is their responsibility, the importance of the contribution made and the frequency with which superiors ask for opinions or suggestions when the budget is being prepared.

\subsection{Managerial Performance}

According to [9], managerial performance is a manager's description of the level of realization of an activity or plan, and the realization of organizational goals, objectives, missions, and visions contained in the organization's strategic plan.

Performance is based on management functions that exist in classical management theory, namely how far managers are able to carry out management functions which include planning, investigation, coordination, evaluation, supervision, staff selection, negotiation and representation [10].

\subsection{Locus of Control}

Locus of control has the meaning of control over belief in oneself, belief in fate, and belief in selfefficacy. There are two groups of locus of control. The first is the internal locus of control where an individual has an expectation that the outcome of their behavior depends on the individual's own behavior. The second is external locus of control where an individual has an expectation that the results they get are a function of luck, destiny, and opportunities that are beyond control or unpredictable.

According to [11], the differences in characteristics between internal and external locus of control are internal locus of control (likes to work hard, having high initiative, always trying to find a solution to the problem, and always trying to think as effectively as possible), and external locus of control (lack of initiative, give up easily, don't like to try because they believe that external factors are in control, lack of information seeking, and having hope that there is little correlation between effort and success)

\subsection{Job Relevant Information}

Job relevant information is information related to the main task where managers can help information about the status of the organization, such as about the level of the organization's economy, finances, and marketing. It is to provide managers with knowledge about alternative decisions and actions needed to achieve better organizational performance and goals effectively and efficiently [1]. Job relevant information related to work is task-related information that can help managers make decisions. With the transfer of information that occurs, it is hoped that related parties can better understand the alternative decisions and actions needed to achieve these goals.

According to the theory developed by [1], job relevant information is measured using the indicators of getting clear information, having adequate information, and obtaining the right and strategic information.

\subsection{Hypothesis}

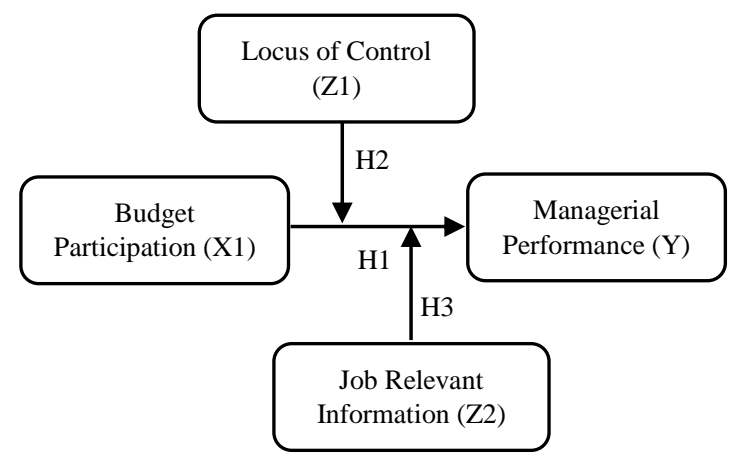

Figure 1 Theoretical Framework

H1: Budgetary participation affects managerial performance

$\mathrm{H} 2$ : Locus of control moderates the effect of budgetary participation on performance managerial

H3: Job relevant information moderates the effect of budget participation on managerial performance. 


\section{RESEARCH METHODS}

The object of this research, namely budgetary participation (X), managerial performance (Y), Locus of Control (Z1), and job relevant information (Z2), was studied at PT. PLN (Persero) UP3 Palu. This research was conducted using a survey method to obtain data from certain natural (not artificial) places. The researchers carried out treatments in data collection, for example by distributing questionnaires, library research and so on [12].

The type of data in this research is quantitative data with primary and secondary data sources. The data collection method used in this study was a questionnaire. The populations in this study are managers, supervisors, and staff who are involved in making the company's budget. Sampling of respondents was carried out with saturated samples. The data in this study were processed using quantitative methods with approaches or with the help of PLS (Partial Least Square). PLS was chosen because the theoretical framework model and the research model built describe the mediating/intervening variable [13].

There are several stages of data analysis using PLS. The limits for rejecting and accepting the estimated parameter significance were above 1.685 for $\mathrm{p}<0.05$ and 2.360 for $\mathrm{p}<0.01$ [14].

\section{RESULTS AND DISCUSSION}

\subsection{Reliability and Validity}

Table 1. Composite reliability value and Cronbach's Alpha

\begin{tabular}{|l|l|l|}
\hline Latent Variable & $\begin{array}{l}\text { Composite } \\
\text { Reliability }\end{array}$ & $\begin{array}{l}\text { Cronbach's } \\
\text { Alpha }\end{array}$ \\
\hline $\begin{array}{l}\text { Budgeting } \\
\text { Participation (PP) }\end{array}$ & 0.819 & 0.740 \\
\hline $\begin{array}{l}\text { Managerial (KM) } \\
\text { Performance (KMtrol }\end{array}$ & 0.928 & 0.908 \\
\hline $\begin{array}{l}\text { Locus of Control } \\
\text { (LOC) }\end{array}$ & 0.979 & 0.977 \\
\hline
\end{tabular}

Source: Processed Data (2020)

Table 1 provides information that the composite reliability value for each variable has a value $>0.70$, meaning that all variables meet the criteria of composite reliability.

The reliability test with composite reliability can be strengthened by using the Cronbach alpha value which is greater than $(\geq) 0.70$ for all constructs. The results indicate that the instruments used to measure the variables have good reliability.
Table 2 presents the Average Variance Extracted (AVE) value which is used as a parameter in evaluating the convergent validity for all variables. The value is greater than $0.50(>0.50)$ which means that it has met the convergent validity criteria. Furthermore, the $p$-value has also met the requirements of $<0.001(<0.05)$ for all variables used in this study.

Table 2. Loading Factor

\begin{tabular}{|c|c|c|c|}
\hline $\begin{array}{l}\text { Latent } \\
\text { Variable }\end{array}$ & $\overline{\text { Loading }}$ & $\begin{array}{l}\text { Latent } \\
\text { Variable }\end{array}$ & $\overline{\text { Loading }}$ \\
\hline $\begin{array}{l}\text { Budgeting } \\
\text { Participation } \\
\text { (PP) } \\
\text { X1 } \\
\text { X2 } \\
\text { X3 } \\
\text { X4 } \\
\text { X5 } \\
\text { X6 }\end{array}$ & $\begin{array}{l}(0.688) \\
(0.590) \\
(0.562) \\
(0.717) \\
(0.714) \\
(0.654)\end{array}$ & 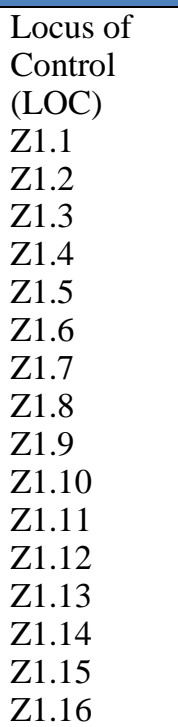 & $\begin{array}{l}(0.963) \\
(0.952) \\
(0.931) \\
(0.875) \\
(0.712) \\
(0.740) \\
(0.832) \\
(0.840) \\
(0.952) \\
(0.954) \\
(0.879) \\
(0.877) \\
(0.782) \\
(0.743) \\
(0.915) \\
(0.842)\end{array}$ \\
\hline $\begin{array}{l}\text { Managerial } \\
\text { Performance } \\
\text { (KM) } \\
\text { Y1 } \\
\text { Y2 } \\
\text { Y3 } \\
\text { Y4 } \\
\text { Y5 } \\
\text { Y6 } \\
\text { Y7 } \\
\text { Y8 } \\
\text { Y9 }\end{array}$ & $\begin{array}{l}(0.898) \\
(0.924) \\
(0.545) \\
(0.533) \\
(0.512) \\
(0.955) \\
(0.534) \\
(0.952) \\
(0.910)\end{array}$ & $\begin{array}{l}\text { Job } \\
\text { Relevant } \\
\text { Information } \\
\text { (JRI) } \\
\text { Z2.1 } \\
\text { Z2.2 } \\
\text { Z2.3 } \\
\text { Z2.4 }\end{array}$ & $\begin{array}{l}(0.697) \\
(0.838) \\
(0.748) \\
(0.854)\end{array}$ \\
\hline
\end{tabular}

Source: Data processed (2020)

Table 3. The value of discriminant validity

\begin{tabular}{|l|l|l|l|l|l|l|}
\hline & PP & KM & BNN & JRI & BNN*PP & JRI*PP \\
\hline PP & $(0.657)$ & 0.334 & -0.253 & -0.290 & 0.027 & -0.073 \\
\hline KM & 0.334 & $(0.777)$ & -0.253 & -0.257 & 0.314 & 0.244 \\
\hline LOC & -0.253 & -0.253 & $(0.866)$ & 0.712 & 0.211 & 0.264 \\
\hline JRI & -0.290 & -0.257 & 0.712 & $(0.787)$ & 0.187 & 0.212 \\
\hline BNN*PP & 0.027 & 0.341 & 0.211 & 0.187 & $(0.475)$ & 0.766 \\
\hline JRI*PP & -0.073 & 0.244 & 0.264 & 0.212 & 0.766 & $(0.520)$ \\
\hline
\end{tabular}

Source: Data processed (2020)

The results showed the square root of average variance extracted (AVE) value as presented on the diagonal line. The square root of average variance extracted (AVE) value obtained has a greater value than the correlation value between the construct and 
other constructs. This greater value of cross loading and square root of average variance extracted (AVE) indicates that the discriminant validity of the instrument in this study is fulfilled. Based on this, it can be concluded that the discriminant validity has been met.

\subsection{Inner Model (structural model)}

The measurement results of the full structural equation model based on data processing using WarpPLS software (Figure 2).

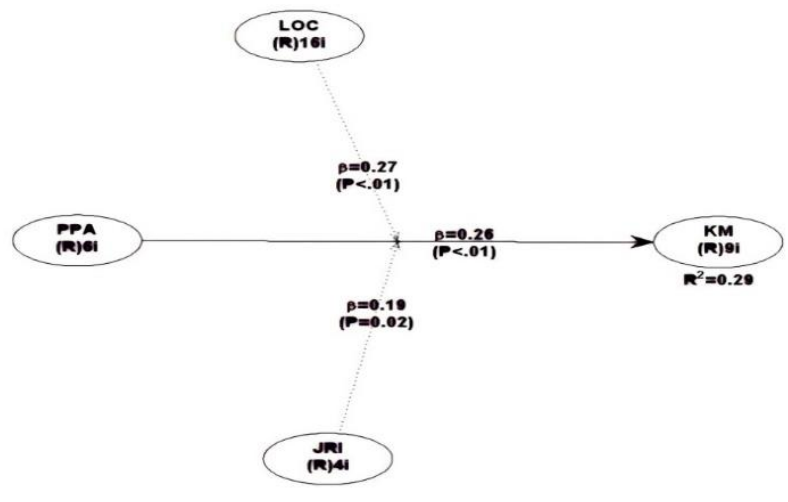

Figure 2 Full Structural Equation Model

Source: Data processed (2020)

Figure 2 indicates that in the empirical research model it is significant where the resulting $\mathrm{p}$-value is $<0.05$.

Table 4. Coefficient Value and p-value

\begin{tabular}{|l|l|l|l|}
\hline $\begin{array}{l}\text { Dependent } \\
\text { Variable }\end{array}$ & PP & BNN*PP & JRI*PP \\
\hline $\begin{array}{l}\text { Managerial } \\
\begin{array}{l}\text { Performance } \\
(\text { KM })\end{array}\end{array}$ & 0.267 & 0.274 & 0.197 \\
$(0.002)$ & $(0.002)$ & $(0.017)$ \\
\hline
\end{tabular}

Source: Data processed (2020)

The results of tests that have been carried out to test several other fit model indicators such as Average path coefficient (APC), Average R-squared (ARS), Average adjusted R-squared (AARS), and Average block VIF (AVIF) and Average block VIF (AVIF) is presented in the Table 5.
Table 5. Fit Model Indicator

\begin{tabular}{|l|l|l|l|}
\hline Parameter & Value & Limitation & Conclusion \\
\hline $\begin{array}{l}\text { Average path } \\
\text { coefficient } \\
\text { (APC) }\end{array}$ & $\begin{array}{l}0.246 \\
\mathrm{P}<0.001\end{array}$ & $\mathrm{p}<0,05$ & Model fit \\
\hline $\begin{array}{l}\text { Average R- } \\
\text { squared } \\
\text { (ARS) }\end{array}$ & $\begin{array}{l}0.295 \\
\mathrm{P}<0.001\end{array}$ & $\mathrm{p}<0,05$ & Model fit \\
\hline $\begin{array}{l}\text { Average } \\
\text { adjusted R- } \\
\text { squared } \\
\text { (AARS) }\end{array}$ & $\begin{array}{l}0.257 \\
\mathrm{P}<0.001\end{array}$ & $\mathrm{p}<0,05$ & Model fit \\
\hline $\begin{array}{l}\text { Average } \\
\text { block VIF } \\
\text { (AVIF) }\end{array}$ & 1.526 & $\begin{array}{l}\text { acceptable if } \\
<=5, \text { ideally } \\
<=3.3\end{array}$ & Model fit \\
\hline $\begin{array}{l}\text { Average full } \\
\text { collinearity } \\
\text { VIF (AFVIF) }\end{array}$ & 2.010 & $\begin{array}{l}\text { acceptable if } \\
<=5, \text { ideally }\end{array}$ & Model fit \\
\hline $\begin{array}{l}\text { Tenenhaus } \\
\text { GoF (GoF) }\end{array}$ & 0.378 & $\begin{array}{l}<=3.3 \\
\text { small }>=0.1, \\
\text { medium > } \\
0.25, \text { large }>=\end{array}$ & Model fit \\
0.36
\end{tabular}

Source: Data processed (2020)

Table 5 yield APC $=0.246 ;$ ARS $=0.295$; and AARS $=0.257$ and all these values are significant at the level $<0.001(<0.05)$. Thus, the goodness of the fit of this research model has been fulfilled [15]; [16].

This result is also supported by AVIF and AFVIF which are used as indicators to see whether or not multicollinearity occurs. The resulting values for AVIF and AFVIF are 1,526 and 2,010, respectively. This value is $<5$. The GoF value of 0.378 indicates that the predictive power of the model is included in the large category $(0.378>0.36)$. Thus, it can be concluded that this research model has met the criteria and there is no problem of multicollinearity between indicators and between exogenous variables.

\subsection{Hypothesis Testing Results}

The first hypothesis states that budgetary participation has a positive effect on managerial performance. The coefficient in the influence between budget participation on managerial performance is 0.26 and the resulting $\mathrm{p}$-value of 0.001 is significant $(<0.05)$. Thus, the first hypothesis is accepted.

The second hypothesis states that locus of control moderates the effect of budgetary participation on managerial performance. The value of the locus of control moderation coefficient is 0.27 and the $p$ value is $0.001<0.05$. Thus, the second hypothesis is accepted. The third hypothesis states that job relevant information moderates the effect of budgetary participation on managerial performance. The coefficient of job relevant information in the relationship between budget participation and 
managerial performance is 0.19 with p-value of $0.02<$ 0.05 . Thus, the third hypothesis is accepted.

\section{CONCLUSION}

Partially, budgeting participation has a positive and significant impact on managerial performance at PT. PLN (Persero) UP3 Palu. This illustrates that budgetary participation can improve managerial performance.

Locus of Control can moderate the influence of budgetary participation on managerial performance. This shows that Locus of Control is the right combination in strengthening the relationship between budgetary participation and managerial performance at the PT. PLN (Persero) UP3 Palu.

Job Relevant Information can moderate the effect of budgetary participation on managerial performance at the PT. PLN (Persero) UP3 Palu. This shows that Job Relevant Information is the right combination in strengthening the relationship between budgetary participation and managerial performance.

\section{AUTHORS' CONTRIBUTIONS}

First Author: writing, data analysis and field research; Second and third authors: method, data analysis; Fourth, fifth and sixth authors: validation.

\section{ACKNOWLEDGMENTS}

Thanks to Tadulako University for providing research and financial support, and to the conference committee for providing the opportunity to present this article.

\section{REFERENCES}

[1] R.A. Bumulo, L. Kalangi, J. Warongan, Pengaruh Partisipasi Penyusunan Anggaran terhadap Kinerja Manajerial dengan Motivasi, Komitmen Organisasi, dan Job relevant information (JRI) sebagai Variabel Moderating pada Perguruan Tinggi Swasta di Provinsi Gorontalo, J. Ris. Akunt. DAN Audit. GOODWILL". 9 (2019).

[2] N. Hapsari, A. Prastiwi, Pengaruh Partisipasi Penyusunan Anggaran terhadap Kinerja Manajerial Dengan Komitmen Organisasi dan Locus Of Control Sebagai Variabel Moderating (Studi Kasus Pada PT Adhi Karya (Persero) Tbk. Divisi Konstruksi I), UNIVERSITAS DIPONEGORO, 2011.

[3] T.I.M. Amertadewi, A. Dwirandra, Pengaruh partisipasi anggaran terhadap Kinerja manajerial dengan gaya kepemimpinan Dan locus of control sebagai variabel moderasi, E-Jurnal Akunt. Univ.
Udayana. 4 (2013) 550-566.

[4] I. Puspita, Pengaruh Partisipasi Penyusunan Anggaran Terhadap Kinerja Aparat Pemerintah Daerah: Rotasi Pekerjaan Dan Job Relevant Information Sebagai Variabel Moderating, Universitas Lampung, 2014.

[5] G.P. Saraswati, M.N. Aisyah, Pengaruh partisipasi penyusunan anggaran terhadap kinerja manajerial dengan job relevant information sebagai variabel moderating (studi pada dinas pemerintah kota Yogyakarta), Nominal Barom. Ris. Akunt. Dan Manaj. 4 (2015), pp 136-147.

[6] N.P. Medhayanti, K.A. Suardana, Pengaruh partisipasi anggaran terhadap kinerja manajerial dengan self efficacy, desentralisasi, dan budaya organisasi sebagai variabel pemoderasi, E-Jurnal Akunt. Univ. Udayana. 1 (2015), pp 155-170.

[7] M.S. Mulyadi, Akuntansi Manajemen: Konsep, Manfaat, dan Rekayasa, 3rd ed., Salemba Empat, Jakarta, 2001.

[8] K. Milani, The relationship of participation in budget-setting to industrial supervisor performance and attitudes: a field study, Account. Rev. 50 (1975), pp 274-284.

[9] Mardiasmo, Akuntansi sektor publik, Andi Offset, Yogyakarta, 2009.

[10] T.A. Mahoney, T.H. Jerdee, S.J. Carroll, The job (s) of management, Ind. Relations A J. Econ. Soc. 4 (1965), pp 97-110.

[11] M.N. Ghufron, R. Risnawita S, Teori-teori psikologi, Ar-Ruzz Media, Yogyakarta, 2010.

[12] Sugiyono, Metode penelitian pendidikan:(pendekatan kuantitatif, kualitatif dan R \& D), Alfabeta, Bandung, 2014.

[13] I. Ghozali, Aplikasi Analisis Multivariate dengan Program IBM SPSS 25, Badan penerbit Universitas Diponegoro, Semarang, 2018.

[14] I. Ghozali, Analisis multivariate lanjutan dengan program SPSS, Badan Penerbit Universitas Diponegoro, Semarang, 2006.

[15] N. Kock, One-tailed or two-tailed $P$ values in PLS-SEM?, Int. J. e-Collaboration. 11 (2015) pp $1-7$.

[16] H. Latan, I. Ghozali, Partial Least Square Konsep, Metode dan Aplikasi Menggunakan WarpPLS 5.0, Badan Penerbit Universitas Diponegoro, Semarang, 2016. 